\title{
Capital Asset Pricing Model (CAPM) and the Douala Stock Exchange
}

\author{
Amenawo Ikpa Offiong ${ }^{1}$, Hodo Bassey Riman ${ }^{1}$, Helen Walter Mboto ${ }^{1}$, Eyo Itam Eyo ${ }^{1} \&$ Diana Gembom Punah ${ }^{2}$ \\ ${ }^{1}$ Department of Banking and Finance, Faculty of Management Sciences, University of Calabar, Nigeria \\ ${ }^{2}$ Catholic University of Cameroun (CATUC), Bamenda, Cameroon \\ Correspondence: Dr Hodo B. Riman, Department of Banking and Finance, Faculty of Management Sciences, \\ University of Calabar, Nigeria. E-mail: horim105@yahoo.com
}

Received: June 9, 2020

doi:10.5430/ijfr.v11n5p191
Accepted: July 28, 2020

Online Published: September 21, 2020

URL: https://doi.org/10.5430/ijfr.v11n5p191

\begin{abstract}
This study examines if the Capital Asset Pricing Model (CAPM) can be applied to the Douala Stock Exchange. The study utilized monthly stock returns from the three companies listed on the Douala Stock Exchange (DSX), for the period 30th April 2009 to 31st August 2017. Ordinary Least Square regression analysis was adopted for the study to examine if individual stocks can predict a better stock beta. The Black, Jensen, and Scholes (1972) CAPM version were also examined in this study to assess the validity of the zero beta estimate. The result of the individual estimates could not establish the validity of the CAPM theory. Further analysis showed that the Beta for the three assets combined portfolio was not statistically significant. However, when two securities were combined into a single asset portfolio, the portfolio bêta was statistically significant. The significant result of the two asset portfolio confirms that Beta was a linear function of security returns in the DSX market. The study concludes that there will be a need for the government of Cameroun to liberalize the DSX market and allow more firms to be quoted on the floor of the exchange. This decision will allow for the deepening of the DSX market, enhance the liquidity level of the market, and enable investors to reap adequate returns from their investment through holding a portfolio of assets.
\end{abstract}

Keywords: Cameroun, stock market, capital asset pricing model, beta, risk premium

\section{Introduction}

Sharpe (1964) and Lintner (1965) were the first researchers to model the CAPM to establish the relationship between risk and returns on assets portfolio. Their model attempted to show that the measure of riskiness (Beta) and risk premium (asset riskiness) did not vary. Generally, the CAPM attempts to predict the expected risk premium for all assets traded in the stock market.

Earlier studies in the stock markets have used the CAPM to understand the relationship between the risks and returns of individual assets and portfolios. These studies agreed that there is a strong correlation between risk and returns regarding individual assets and portfolios. However, recent studies in the 21 st century adopted an alternative methodology for testing CAPM using the beta coefficient, a statistical measure of risk and returns. The Beta of individual security measures the sensitivity of the asset to the movement of the market. The more volatile the asset in the market is, the more the risk associated with the asset. Beta is, therefore, the measure of the riskiness of the asset with the market movement. The more responsive an asset's price is to the movement in the market, the higher the asset's Beta will be. CAPM predicts that the higher the volatility of the asset price, the higher the expected returns from the market. The value of the total risk associated with assets traded in every market consists of both the diversifiable and non-diversifiable risk. The diversifiable risk can be dissipated by holding a large number of carefully selected securities. Therefore, an investor would want to maximize their expected returns subject to their level of risk tolerance.

The beta coefficient can be positive or negative, while Beta for all markets is expected to be positive and lie above + 1 , most Beta lie somewhere between +1 and +4 (Fischer and Jordan, 2005). A beta above 1.0 means the stock's risk is above the average market returns.

A beta lower than 1.0 shows an asset's riskiness is lower than normal market returns. To outline, a beta of 1.80 on a stock ought to have increment returns around 18 per cent at the same time when the pace of return is assessed at 10 per cent. Similarly, if the market is expected to experience a negative return of 10 per cent, then stock with a beta of 1.8 per cent should be expected to decline 18 per cent in returns. 
Cameroun stock market is characterized by low liquidity, low level of investment, and poor market participation. Following this scenario, the government established the Douala Stock Exchange (DSX) not only to increase investor's participation, thereby deepening the market, but also to allocate extra resources to the firms, increase investment and help quoted firms to adapt to global challenges (Ake and Ognaligui, 2016).

The DSX was established to set the rules that would, among other things, regulate access to the market and admission of listed stocks into the market. As observed by Ndedi, Kuete, Mua, and Banaken (2018), almost 14 years after the establishment of DSX, the market has failed to live up to its expectation despite government implementing financial liberalization policy. Additionally, the authors attributed the failure of DSX to regulate the Cameroon Stock Market to the inability of the instrument traded to meet the requirements of some players in the market.

Previous studies carried out on the Cameroun DSX market had focused on the contributions of the stock market to economic growth (Boubakari 2010) and (Becke and Tasoh 2016). As far as we could know, no investigation has been led to testing any of the CAPM on the Douala Stock Exchange (DSX). The absence of any empirical research concerning the risk-return relationship in the DSX market necessitated this study. Therefore, the study sets out to empirically consider whether the application of the CAPM on the DSX market can predict the performance of risk-returns relationship of the assets traded in the stock exchange. In fulfilling the stated objective, the study will adopt a step application model. The first model will examine the application of CAPM on individual stocks. The second model will examine if the application of CAPM on the portfolio(s) of the stocks traded on the DSX will explain the linearity of the risk-return relationship.

\section{Empirical Literature}

Several empirical studies have been carried out to ascertain the validity of CAPM on markets after the popularization theories of William Sharpe, John Lintner and Jack Treynor in the mid-1960s. While some authors did not show evidence to support CAPM's validity in some markets, other authors acknowledge that CAPM prediction "that is the higher the risk, the higher the returns" does hold among individual assets.

Choudhary and Choudhary (2010) studied the CAPM model on stocks traded on the Indian Equity market using the monthly stock report from January 1996 to December 2009. Their result observed that CAPM does not support the evidence that Beta was significant in the market; the study negates the CAPM's theoretical prediction that the slope should equal the excess returns on the market portfolio. The intercept should equal zero. However, the study came out with major findings that residual risk does not affect the expected returns of portfolios. Importantly, the study further expresses the nonlinearity relationship between returns and Beta.

Yasmeen, Awan, Ghuari, and Waqas (2012) investigated the validity of the CAPM in the Pakistan Stock Market using daily stock returns of 20 companies listed in the KSE. A two-step regression analysis was adopted in the study to establish the regression equation. The authors' results were unique in three ways (1) CAPM does not explain the movement of returns in the market (2) the hypothesis that market premium is a significant variable in explaining risk premium was rejected (3) risk and returns are covariates. The study concluded that market risk alone doesn't explain excess return, but also a unique risk is essential in contributing to excess return.

Wu, Imran, Feng, Zhang and Abbas (2017) investigated CAPM's validity in predicting the risk-return relationship in the Pakistan Stock exchange using data from 306 non-financial firms throughout January 2001 to December 2015 using two-pass regression analysis. The result of the first pass analysis did not find evidence to suggest the existence of CAPM in predicting the Pakistan Stock Market. The second pass regression analysis did not also find evidence to suggest that expected returns correspondingly relate to actual return in the market. The result obtained by these authors collaborates with the results obtained by Eitizaz and Attiya (2008).

Bhatt and Chauhan (2016) examine CAPM's claims using selected companies of BSE Sensex on the Indian stock market. The study utilized the top five major companies based on their high turnover from 2005 to 2015. The result of their study observed that there exists a difference between risk and actual returns. Their result does not find evidence that there is a linear relationship between risks and return influences on the market.

Rizwan, Shaikh and Shehzadi (2013) investigated the validity of CAPM application to the cement sector of the Karachi Stock exchange using monthly returns from January 2004 to December 2009. This study demonstrated that Beta is not a good predictor of asset returns, particularly regarding individual assets. However, when considering portfolio returns, the result demonstrated that residual risk does not affect a portfolio's expected returns.

Some authors have attempted to examine if the number of quoted companies determines the CAPM model's validity. Nyangara, Nyangara, Ndlovu and Tyavambiza (2016) used stock of 31 listed companies between March 2009 and February 2014 to empirically investigate the validity of CAPM on the Zimbabwe Stock exchange. Their result 
brought to fore the following observation (1) beta significantly explained average monthly stock returns on the ZSE (2) CAPM failed to predict the market returns for ZSE. However, CAPM was successful in explaining the firms' average monthly returns over a 3 to 6 months horizon. The authors had reasons to believe that the size of the market did not have any reason to justify the invalidity of the CAPM as regards the ZSE market.

However, Wakyiru (2010) opinion does not seem to collaborate with the opinion of Nyangara, Nyangara, Ndlovu and Tyavambiza (2016) when he examined the validity of the Capital Asset Pricing Model (CAPM) on the Ugandan stock market using monthly stock returns. Specifically, the study examined the Black, Jensen, and Scholes (1972) version of the CAPM on the Ugandan stock market. This study showed that while the estimated portfolio beta was statistically significant, such evidence was observed when the zero Beta was tested. The significance of the portfolio beta proved that CAPM holds when only assets are held in portfolios.

Jamil (2018) examined CAPM's validity on the London Stock Exchange (LSE) market using share prices of 70 most traded companies holding in FTSC 100 for the period 2004 to 2016. The empirical result, although shows evidence that returns are directly associated with risk. However, various portfolios were observed to have low Beta and high returns. Conclusively, the author's empirical study supported the CAPM to predict turnover for the companies between 2004 and 2016, particularly since the main characteristics of assets proved that risk doesn't impact portfolio returns.

Alagidede, Koutounidis, and Panagiotidis (2017) examined if CAPM's application would help stabilize and insulate the Johannesburg Securities Exchange (JSE) from the global financial crisis. The study used firms' betas derived from OLS and M-estimation regressions. Their result suggested that stable Beta were only obtained after the global financial crisis. However, stable Beta was obtained when the non-linear paradigm was applied to the analysis.

Elshqirat and Sharifzadeh (2018) examined the validity of single-factor CAPM while also testing for multi-factor CAPM on the Jordanian stock market using companies quoted on the Amman stock exchange from 2000 to 2015. They observed that company size and financial leverage do not influence the expected return rate. The inference of this result revealed that company size and the company capital structure might not be a force in predicting the returns of the assets in the market.

There have also been several demonstrations to prove that CAPM's validity in determining the risk-return relationship depended on the methodology applied in the study. For instance, Karakok (2017) examined the existence of a linear relationship between stock beta and returns following CAPM predictions. The result of this study agrees that the risk-return relationship holds in explaining changes in the rate of profit. The study further observed that the risk-return relationship between the beta coefficient and returns could also be negative.

Archeampong and Agalega (2013) examined the predictability of stock returns using CAPM on the Ghanaian Stock Market. The results obtained from the study using linear regression revealed that constant Beta was insignificant, thus signifying that the actual returns and the predicted returns series using CAPM does not hold. The study concluded that the perceived variations in the risk-return relationship were not due to systematic risk factors (as predicted by CAPM). Rather, the changes that were observed can be said to occur by chance.

Hasan, Kamil, Mustafa, and Baten (2015) investigated if CAPM can predict the returns for the Dhaka Stock Exchange using monthly stock returns of 80 non-financial companies. Their study observed that a linear relationship did not exist between beta and share return, although the value of zero Beta was significantly different from zero. The study, therefore, refuted the CAPM hypothesis and offered evidence of the nonexistence of the CAPM in the Dhaka Stock Market.

Janata (2016) examined the validity of CAPM for securities traded on the Nairobi Stock Exchange (NSE) using the Fama and Macbeth (1973) two-pass regression method applied to 18 firms traded at NSE. The result of this study rejected the application of CAPM in explaining the risk-return relationship. The study also negated the hypothesized zero beta value for the intercept and linear risk-return relationship. The study supported the belief that increasing the number of stocks traded in the market could improve the validity of the risk-return results.

The literature reviewed has significantly revealed there exist a linear relationship between risk and returns across markets, while beta was also found to be positive and significant at 5 percent. Most of the literature reviewed had focused their empirical investigations on large, organized and well developed market where all forms of restrictions and regulations have been removed. Similar studies were not carried out on small markets that are characterized with rigidities, restriction to entry of more firms into the market and week regulatory framework. The Cameroun DSX market is a small market and underdeveloped market that has only three firms participatory firms. The study 
therefore, seeks to examine if the CAPM assumptions can also hold in this market as it holds in other developed market.

\section{Methodology}

Data for Douala Stock Exchange monthly stock prices of stocks traded will be applied from April 2009 to August 2017 to test the Capital Asset Pricing Model. The Cameroun stock exchange has only three stocks traded on the floor of the market, viz, SEMC, SAFACAM and the SOCAPALM. Thus, the study will utilize 302 monthly return observations for all companies in the DSX exchange.

The equity stocks closing price data were collected from the DSX market reports, tabulated and converted into monthly holding period returns. The data on the Dow Jones industrial average and the DSX 13 weeks (91 days) Treasury bill was used as a proxy for the market return and the risk-free rate.

The study begins by calculating the individual stock returns using the formula

$$
\mathrm{R}_{\mathrm{it}}=\log \mathrm{P}_{\mathrm{it}}-\log \mathrm{P}_{\mathrm{it}-1}
$$

Where

$R_{i t}-$ Return of security i at time $t-1$ and $t$ is expressed in logarithmic form

$P_{i t}$ - Closing price of security $i$ on the current day of trading $t$,

$P_{i t ~-~}$ - Closing price of security $i$, on the previous day of trading, i.e., $t-1$

Secondly, we test the applicability of the CAPM using the relationship, as expressed below.

$$
\mathrm{R}_{\mathrm{it}}-\mathrm{R}_{\mathrm{ft}}=\alpha_{\mathrm{t}}+\beta_{\mathrm{t}}\left(\mathrm{R}_{\mathrm{mt}}-\mathrm{R}_{\mathrm{ft}}\right)+\varepsilon_{\mathrm{it}}
$$

The above formulae can be interpreted as thus:

Expected risk premium on stock $=$ beta $\mathrm{x}$ expected risk premium on the market.

In a volatile market, the expected risk premium moves in direct proportion to Beta, following from the assumption that every investor holds a market portfolio and beta measures each security contribution to the market portfolio risk.

The average portfolio excess return was calculated using Michailidis, Papanastasiou, and Mariola's (2006) model. The study adopted these authors' models based on the peculiarity of the DSX, which has only three stocks traded in the market. The three DSX stocks were combined into a single equally-weighted portfolio, and the excess portfolio returns calculated as

$$
r_{p t}=\frac{\sum_{i=1}^{k} r_{i t}}{k}
$$

Where,

$\mathrm{k}=$ the number of stocks included in each portfolio,

$\mathrm{p}=$ the number of portfolios

$\mathrm{r}_{\mathrm{it}}=$ the excess return on companies' securities.

The portfolio beta can, therefore, be estimated as:

$$
r_{p t}=\alpha_{p}+\beta_{p} r_{w t}+e_{p t}
$$

Where,

$\beta_{\mathrm{p}}=$ the Beta of portfolio $\mathrm{p}$,

$\mathrm{r}_{\mathrm{mt}}=$ the average risk premium and

$\mathrm{e}_{\mathrm{pt}}=$ the random disturbance term in the regression equation,

\section{Analysis and Discussion of Result}

The analysis of CAPM's application to the DSX market began with the calculation of the individual stock beta coefficient. The result of the estimated beta coefficient is presented in Table 1. 
Table 1. Individual stock beta estimates

\begin{tabular}{llllll}
\hline Stock name & Beta $(\boldsymbol{\beta})$ & t-value & Std. Error & $\mathbf{R}^{2}$ & $\begin{array}{l}\text { Expected return } \\
\left\{\mathbf{r}_{\mathbf{f}}+\boldsymbol{\beta}\left(\mathbf{r}_{\mathbf{m}}-\mathbf{r}_{\mathbf{f}}\right\}\right.\end{array}$ \\
\hline SEMC & 0.089622 & 1.13319 & 0.07908864 & 0.012934 & 12.77 \\
\hline SOFACAM & 0.156225 & 1.611186 & 0.09696257 & 0.025805 & 12.31 \\
\hline SOCAPALM & 0.031122 & 0.347356 & 0.08959583 & 0.00123 & 12.88 \\
\hline
\end{tabular}

The result presented in Table 1 reveals that Beta for the assets ranges from 0.03 to 0.15 . SOCOPALM has a low-risk premium of $0.03(3 \%)$ but has an expected return of $12.88(12.88 \%)$. SEMC has a risk premium of 8 per cent but with an expected return of 12.77 per cent, while SAFACAM, which has a risk premium of 15 per cent, has the lowest expected return of 12.31 per cent. Although none of the Beta's coefficients was significant at 5 per cent, the risk-return relationship defied the CAPM prediction. The result could suggest that investors in this market may choose to be risk-averse by choosing a lower risk-return relationship. It can, however, be observed that the R2 for the regression is very low. The value of low R2 could mean that the Beta is inefficient to measure the market risk.

Although the individual coefficients of Beta are not statistically significant, this should not lead us to conclude that the market does not follow the CAPM unless we observe the values of the coefficients of the zero Beta. CAPM had predicted that the zero Beta should be positive and zero for all assets.

Table 2. The result of the intercept of zero Beta

\begin{tabular}{llllll}
\hline Stock name & Zero Beta $(\boldsymbol{\beta})$ & t-value & Std. Error & $\mathbf{R}^{2}$ & P-Values \\
\hline SEMC & -0.1255 & -24.9212 & 0.005036 & 0.012934 & 0.0000 \\
& & & & & \\
\hline SAFACAM & -0.11918 & -19.3039 & 0.00617413 & 0.025805 & 0.0000 \\
& & & & & \\
\hline SOCAPALM & -0.12804 & -22.4428 & 0.00570505 & 0.00123 & 0.0000 \\
\hline
\end{tabular}

It is observed from the result above that the coefficients of zero Beta though negative but were all statistically significant and different from zero. The two previous analyses bring very salient factors to bear regarding the Cameroun stock market - (1) The individual betas of the asset were not statistically significant, and (2) the zero betas were negative even though they were statistically significant and different from zero. Given the non-validity of individual assets beta, do we assume that CAPM cannot be said to hold for the Cameroun Stock Market? According to Wakyiku (2010), this does not necessarily hold since individual assets can be affected by white noise, therefore to ascertain the validity of CAPM Black, Jensen and Scholes (1972) suggested creating portfolios with different Beta for sufficient empirical evidence. Hence, to regress a single portfolio of assets, the market's three asset portfolios were pooled together.

Hence, to regress a single portfolio of assets, the market's three asset portfolios were pooled together.

Table 3. Portfolio Beta estimate for three assets model

\begin{tabular}{llllll}
\hline Stock name & Beta $(\boldsymbol{\beta})$ & t-value & Std. Error & $\mathbf{R}^{2}$ & P-Values \\
\hline & 0.091711 & 1.435271 & 0.06389798 & 0.020588 & 0.154394 \\
\hline
\end{tabular}

From Table 3, it is observed that the portfolio beta though positive but was not significant at 5 per cent. The above result does not support the validity of CAPM predicting the risk-returns relationship of the portfolio beta when entire assets in the market are combined into a single portfolio. The non-validity of the portfolio beta is also confirmed by the low R2 (0.02).

The findings of this result collaborate with the findings of Basu and Chawla (2010). 
In such a market where the CAPM prediction does not hold, how would investors maximize their expected returns while attempting to reduce their risk? Sharpe (1964), Brealey and Myers (1996) suggest that a little diversification combined with holding a few assets in a portfolio can reduce the variability of risk and maximize returns. The portfolio beta is simply the weighted average of the Beta of the component securities.

To examine if risk can be reduced in the market through the combination of two assets in a portfolio, the study, constructed a two-asset portfolio of assets traded in the DSX market through applying equal weight to each asset in the portfolio. The equal weighting of the assets was done on the assumption that investors will desire to spread equal funds amongst all the assets in the portfolio, thus reducing idiosyncratic risk.

Table 4. Portfolio combination of assets

\begin{tabular}{lllllll}
\hline Portfolios & Beta $(\boldsymbol{\beta})$ & t-value & Std. Error & $\mathbf{R}^{2}$ & P-Values & $\begin{array}{l}\text { Expected } \\
\text { return }\end{array}$ \\
\hline SEMC_SOFACAM & 0.691711 & 2.063139 & 0.335271 & 0.20 & 0.0154394 & 1.0227 \\
\hline SOFACAM_SOCAPALM & 0.536731 & 2.093146 & 0.396423 & 0.13 & 0.0143252 & 0.9842 \\
\hline SEMC_SOCAPALM & 0.486518 & 1.273124 & 0.382145 & 0.23 & 0.0215261 & 0.5973 \\
\hline
\end{tabular}

The result from Table 4 reveals that idiosyncratic risk has been spread efficiently following the combination of two assets in a portfolio. The combination of SECM and SOFACAM assets yielded a beta of 0.69, an expected average return of 1.022 and a p-value of 0.0154 .

According to Fischer and Jordan (2005), a beta of +1.0 indicates a stock with average volatility relative to the market. If the market return were forecasted at 10 per cent, the stock would be estimated to have a return of 10 per cent. SOFACAM and SOCAPALM portfolio had a beta of 0.53 and an expected return of 0.984 while the combination of SEMC and SOCAPALM had a beta of 0.48 and an expected return of 0.59 . The result revealed that portfolio combination in the DSX market confirms CAPM prediction regarding the risk-return relationship since the betas were statistically different from zero at a 5 per cent level.

\section{Conclusion}

The study seeks to test CAPM's applicability in determining the risk-return relationship of assets traded on the Cameroon Stock Market. The study used monthly stock returns from three companies between April 2009 and August 2017. The findings from the study could not establish CAPM theory that higher risk (Beta) is associated with a higher level of return holds in the Cameroun DSX market. However, to diversify the riskiness of the firms' assets, three assets were combined into one single portfolio using equal weights. The study observed that the portfolio beta of the three-asset combined portfolio was not significantly different from zero. However, when two assets were combined into single portfolios, the result of the portfolios Beta revealed that the linear structure of the CAPM equation was a good predictor of security returns.

The CAPM theory's inability to hold regarding the individual securities in the DSX market could be attributed to the low depth of the market arising from a limited number of securities traded in the market and lack of confidence and trust exhibited by investors regarding the operational nature of the market. Following these limitations, it will not be sufficient to conclude that the CAPM theory will not hold on the Cameroun DSX until its sufficiently deepened by encouraging the enlistment of more securities into the market. This opinion also collaborates the position previously opined by Banz, (1981) and Basu, (1983).

\section{References}

Acheampong, P., \& Agalega, E. (2013). Does the capital assets pricing model (CAPM) predicts stock market returns in Ghana? Evidence from selected stocks on the Ghana Stock Exchange. Research Journal of finance and accounting, 4(9), 27-35.

Ake, B., \& Ognaligui, R. W. (2016). Financial stock market and economic growth in developing countries: The case of Douala Stock Exchange in Cameroon. International Journal of Business and Management. Retrieved from http://ssrn.com/abstract=2012515 
Alagidede, P., Koutounidis, N., \& Panagiotidis, T. (2017). On the stability of the CAPM before and after the financial crisis: Panel evidence from the Johannesburg Securities Exchange. African Review of Economics and Finance, 9(1).

Backe, I., \& Tasho, T. (2016). A 10 year (2006-2015) performance analysis of the Douala Stock Exchange Market, SSRN Electronic Journal.

Banz, R. W. (1981). The relationship between return and market value of common stocks. Journal of Financial Economics, 9, 3-18.

Basu, S. (1983). The relationship between earnings yield, market value and the return for NYSE common stocks. Journal of Financial Economics, 12, 126-156.

Bhatt, B., \& Chauhan, A. (2016). Examining validity of capital asset pricing model with reference to selected companies of BSE Sensei. Sabargam International Journal of Research in Multidiscipline, 1(1).

Black, F., Jensen, M. C., \& Scholes, M. (1972). The capital asset pricing model: Some empirical tests. Studies in the Theory of Capital Markets, 79-121.

Boubakari, A., \& Rachelle, W. O. (2010). Financial stock market and economic growth in developing countries: The case of stock exchange in Cameroon. International Journal of Business Management.

Brealey, R. A., \& Myers, S. C. (1996). Principles of Corporate Finance (5th ed.). McGraw-Hill Companies, Inc. USA.

Choudhary, K., \& Choudhary, S. (2010). Testing capital asset pricing model: Empirical evidences from Indian equity market. Eurasian Journal of Business and Economics, 3(6), 127-138.

Eatzaz, A., \& Attiya, J. (2008). Testing multifactor capital asset pricing model in case of Pakistani market. International Research Journal of Finance and Economics, (25), 114-138. Retrieved from https://mpra.ub.uni-muenchen.de/id/eprint/37341

Elshqirat, M. K., \& Sharifzadeh, M. M. (2018). Testing a multi-factor capital asset pricing model in the Jordanian Stock Market. International Business Research, 11(9). https://doi.org/10.5539/ibr.v11n9p13

Fama, E. F., \& Macbeth, F. D. (1973). Risk, return and equilibrium: Empirical tests. The Journal of Political Economy, 81(3), 607-636.

Ferruz, L., Marco. I., \& Rivas, F. J. (2007). Stock market indices and investment funds. An empirical approach in the Spanish and European context. Journal of Applied Science, 7, 633-653.

Fischer, D. A., \& Jordan, R. J. (2005). Security Analysis and Portfolio Management (6th ed.). Prentice-Hall of India Private Limited, New Delhi.

Hasan, Z., Kamil, A. A., Mustafa, A., \& Baten, A. (2013). Analyzing and estimating portfolio performance on the Bangladesh stock market. American Journal of Applied Sciences, 10(2), 139-146.

Janata, G. (2016). Validity of the capital asset pricing model (CAPM) for securities trading at the Nairobi Securities Exchange (NSE). Business and Management Research, 5(4). https://doi.org/10.5430/bmr.v5n4p62

Jensen, M. C., Black, F., \& Scholes, M. (1972). The capital asset pricing model: Some empirical tests. In C. M. Jensen (Ed.), Studies in the theory of capital markets (pp. 79-121). New York, NY: Praeger.

Karakoc, B. (2016). A validity of capital pricing model (CAPM) in Istanbul market. Journal of Social Science of Mus Alparslan University, 4(1). https://doi.org/10.18506/anemon.09569

Lintner, J. (1965). The valuation of risk assets and the selection of risky investments in stock portfolios and capital budgets. Review of Economics and Statistics, 47(1), 13-37. https://doi.org/10.2307/1924119.

Michaildis, G. S., Papanastasiou, T. D., \& Mariola, E. (2006). Testing the capital asset pricing model (CAPM): The case of the emerging Greek securities market. International Research Journal of Finance and Economics, 4.

Ndedi, A., Kuete, Y. D., Mua, K. K., \& Banaken, J. (2017). The Douala Stock Exchange (DSX) in Cameroon and its Discontents. Retrieved from https://ssrn.com/abstract=2678897

Nyangara, M., Nyangara, D., Ndlovu, G., \& Tyavambiza, T. (2016). An empirical test of the validity of the capital asset pricing model on the Zimbabwe Stock Exchange. International Journal of Economics and Financial Issues, 6(2), 365-379. 
Rizwan, S., Shaikh, S., \& Shehzadi, M. (2013). Validity of capital assets pricing model (CAPM): Evidence from cement sector of Pakistan listed under Karachi Stock Exchange. Kuwait Chapter of Arabian Journal of Business and Management Review, 2(6).

Sharpe, W. F. (1964). Capital asset prices: A theory of market equilibrium under conditions of risk. Journal of Finance, 19(3), 425-42. https://doi.org/10.1111/j.1540-6261

Wakyiku, D. (2010). Testing the capital asset pricing model (CAPM) on the Uganda Stock Exchange. Retrieved from https://arxiv.org

Wu, M., Imran, M., Feng, Y., Zhand, L., \& Abbas, M. (2017). Review and validity of capital asset pricing model: Evidence from Pakistan stock market. International Research in Economics and Finance, 1(1). Retrieved from 10.20849/iref.vlil.267

Yasmeen, A., Awan, M., Ghuari, S., \& Waqas, M. (2012). The capital asset pricing model: Empirical evidence from Pakistan. MPRA Paper No. 41961. Retrieved from https://mpra.ub.uni-muenchen.de/41961/

\section{Copyrights}

Copyright for this article is retained by the author(s), with first publication rights granted to the journal.

This is an open-access article distributed under the terms and conditions of the Creative Commons Attribution license (http://creativecommons.org/licenses/by/4.0/). 